\title{
Developmental Changes in Glucose Transport of Guinea Pig Erythrocytes
}

\author{
TAKahito Kondo and ERNEST BeUTLER, Department of Hematology, City of \\ Hope Medical Center, Duarte, California 91010
}

A B S TRACT The developmental changes in the capacity for D-glucose transport of guinea pig erythrocyte membranes were compared to alterations in the electrophoretic pattern of erythrocyte membrane components. Guinea pig erythrocytes lose their D-glucose carrier functions during development. Good correlation was observed between the loss of glucose uptake and apparent decrease of the zone 4.5 of Coomassie Bluestained membrane proteins on electrophoresis. Reconstitution of membrane preparations in liposomes resulted in a parallel change in the D-glucose uptake and D-glucose penetration of intact erythrocytes.

This suggests that the decrease of D-glucose transport capacity during development is caused by the loss of one or more protein components from the erythrocyte membranes.

\section{INTRODUCTION}

Using a carrier system located in the membrane, D-glucose and several other hexoses readily enter human erythrocytes. Recent studies of this system have suggested that subunits of the carrier protein are located in the area designated as zone 4.5 on sodium dodecyl sulfate polyacrylamide gel electrophoresis (SDSPAGE) ${ }^{1}(1-3)$. The erythrocytes of most newborn mammals also have the capacity to facilitate the transport of glucose, but in some species the permeability of erythrocytes to glucose is rapidly lost with maturation $(4,5)$. This developmental loss of glucose transport provides us with an opportunity to compare the changes in membrane proteins to the loss of capacity to transport glucose. We have chosen the guinea pig as a convenient experimental animal in which to carry out such investigations.

Dr. Kondo's and Dr. Beutler's present address is Department of Clinical Research, Scripps Clinic and Research Foundation, La Jolla, Calif.

Received for publication 22 June 1979 and in revised form 13 August 1979.

${ }^{1}$ Abbreviation used in this paper: SDS-PAGE, sodium dodecyl sulfate polyacrylamide gel electrophoresis.

\section{METHODS}

D-[ $\left.{ }^{14} \mathrm{C}\right]$ glucose, $\mathrm{L}-\left[{ }^{14} \mathrm{C}\right]$ glucose and ${ }^{125} \mathrm{I}$ albumin were purchased from New England Nuclear (Boston, Mass.), L- $d$-phosphatidylcholine from Sigma Chemical Co. (St. Louis, Mo.), DEAEcellulose from Pharmacia Fine Chemicals (Piscataway, N. J.), Bio-Beads SM-2 from Bio-Rad Laboratories (Richmond, Calif.), and Diaflo Ultrafilter PM 10 from Amicon Corp., Scientific Sys. Div. (Lexington, Mass.). Blood from guinea pigs was collected in $1 \mathrm{mg} \mathrm{EDTA} / \mathrm{ml}$ and was freed of leukocytes and platelets by passing through a small column of $\alpha$-cellulose microcrystalline cellulose (6).

Estimation of the glucose permeability. The erythrocytes were washed three times with $0.128 \mathrm{M}$ sodium chloride solution containing $14 \mathrm{mM} \mathrm{Na}_{2} \mathrm{HPO}_{4}$ and $6 \mathrm{mM} \mathrm{NaH}_{2} \mathrm{PO}_{4} .1 \mathrm{ml}$ of erythrocytes was added to $9 \mathrm{ml}$ of $300 \mathrm{mM}$ D-glucose in the same buffer containing $0.35 \mu \mathrm{Ci}^{125} \mathrm{I}$-albumin $/ \mathrm{ml}$. The suspensions of erythrocytes were incubated at $25^{\circ} \mathrm{C}$ and samples were removed at intervals and centrifuged $1,000 \mathrm{~g}$ for $5 \mathrm{~min}$ in microhematocrit tubes. The glucose concentration of perchloric acid extracts from the pellets was estimated enzymatically using the hexokinase system (7). Correction for trapped fluid was made on the basis of the ${ }^{125}$ I activity.

Preparation of erythrocyte membranes and purification of zone 4.5. Ghosts were prepared from fresh guinea pig erythrocytes by the method of Dodge et al. (8) with $10 \mathrm{mM}$ Tris$\mathrm{HCl}, \mathrm{pH}$ 7.4. A membrane suspension containing $\sim 3 \mathrm{mg}$ protein $/ \mathrm{ml}$ was ireated with $10 \mathrm{vol} 0.1 \mathrm{mM}$ EDTA, pH 8.0, for $1 \mathrm{~h}$ at $37^{\circ} \mathrm{C}$. After centrifugation at $78,000 \mathrm{~g}$ for $30 \mathrm{~min}$ at $4^{\circ} \mathrm{C}$, the pellet was washed with $4 \mathrm{vol}$ of the EDTA solution and centrifuged. It was then treated with $4 \mathrm{vol}$ of $0.5 \mathrm{M} \mathrm{NaCl}$, $5 \mathrm{mM}$ Tris- $\mathrm{H}_{2} \mathrm{SO}_{4}, \mathrm{pH} \mathrm{7.4,} \mathrm{for} 1 \mathrm{~h}$ at $4^{\circ} \mathrm{C}$ followed by centrifugation. The pellet was washed once with 2 vol of the same salt solution, according to the procedures of Fairbanks et al. (9), and Kasahara and Hinkle (1), with slight modifications. This procedure removed spectrin and other extrinsic proteins from membranes. The pellet was incubated with $0.5 \%$ Triton $\mathrm{X}-100$, Rohm and Hass Co. (Philadelphia, Pa.), in $10 \mathrm{mM}$ Tris- $\mathrm{HCl}$, $\mathrm{pH} 7.4$, for $20 \mathrm{~min}$ at $4^{\circ} \mathrm{C}$, and centrifuged at $100,000 \mathrm{~g}$ for $1 \mathrm{~h}$ at $4^{\circ} \mathrm{C}$, as reported (1). The Triton extract containing $\sim 5 \mathrm{mg}$ of protein, was applied to a $1.2 \times 10-\mathrm{cm}$ DEAE-cellulose column previously equilibrated with $0.5 \%$ Triton $\mathrm{X}-100$ in $50 \mathrm{mM}$ Tris- $\mathrm{HCl}, \mathrm{pH} \mathrm{7.4}$. The column was eluted with $20 \mathrm{ml}$ of the same buffer. The eluate representing partially purified 4.5, was concentrated using an Amicon PM10 filter. Triton X-100 was removed using Bio-Beads SM-2 (10).

Reconstitution and assay of glucose uptake system. Membrane extracts $(56-310 \mu \mathrm{g})$ that had been freed of Triton X-100, were reconstituted in liposomes in a total volume of $1 \mathrm{ml}$ according to the method of Kasahara and Hinkle (1). Glucose uptake was measured at $25^{\circ} \mathrm{C}$ for $1 \mathrm{~min}$. The assay system con- 
tained $47.5 \mu \mathrm{l}$ of the reconstituted liposomes in $10 \mathrm{mM}$ Tris$\mathrm{HCl}, \mathrm{pH} 7.4$, containing $2 \mathrm{mM} \mathrm{MgCl}_{2}$ and $2.5 \mu \mathrm{l}$ of $1.7 \mathrm{mM}$ D- or L- $\left[{ }^{14} \mathrm{C}\right]$ glucose.

Analytical methods. Protein concentrations were estimated by the method of Lowry et al. (11) with bovine serum albumin as a standard. SDS-PAGE was performed according to the methods of Fairbanks et al. (9). Gels stained with Coomassie Blue were scanned at $550 \mathrm{~nm}$ using a Gilford spectrophotometer, Gilford Instrument Laboratories, Inc. (Oberlin, Ohio) and the quality of protein in each band was estimated by weighing cut out portions of the scanning pattern.

\section{RESULTS}

Effect of age on glucose penetration into intact erythrocytes of guinea pigs. The rate of penetration of D-glucose was estimated with erythrocytes from guinea pigs aged from $1 \mathrm{~d}$ to $7 \mathrm{mo}$. As shown in Fig. 1, the rate of penetration of D-glucose decreased rapidly during the first $30 \mathrm{~d}$ after birth, and by $\sim 7 \mathrm{mo}$, guinea pig erythrocytes were impermeable to glucose.

SDS-PAGE electrophoretogram of membrane fractions. The electrophoretogram of guinea pig erythrocyte ghosts was very similar to that of human ghosts except for band 4 , which in human membranes divided into 4.1 and 4.2 but consists of only a single sharp peak in the case of guinea pig membranes. When human erythrocyte membranes are subjected to electrophoresis a single broad band is found between the band 4.1 and 4.2 complex in band 5 . This band has been designated by Steck (12) as zone 4.5. Fig. 2 shows the SDS-PAGE pattern of ghosts at each developmental stage. An apparent decrease in the amount of protein in zone 4.5 is observed during development. Zone 4.5 of a 1-d, 1-,

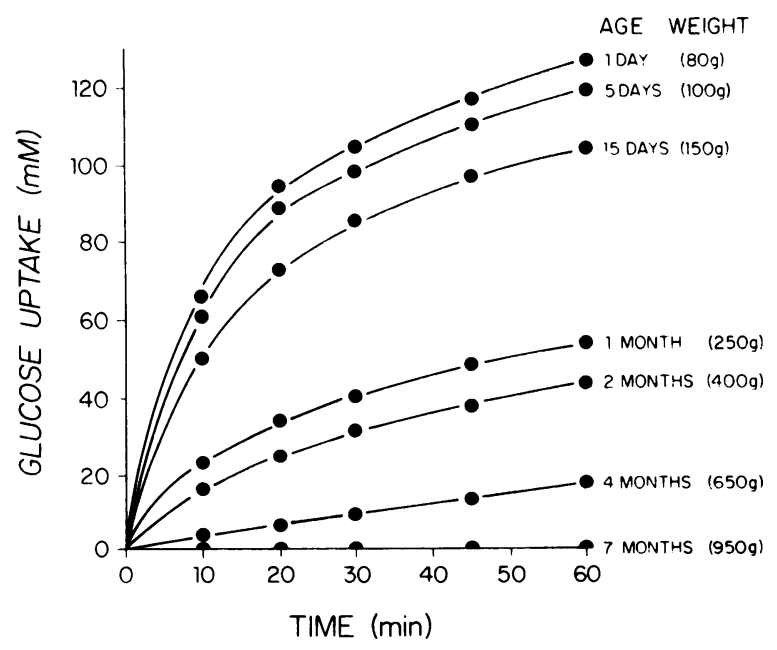

FIGURE 1 D-Glucose uptake by guinea pig erythrocytes as a function of time of incubation. Erythrocytes were incubated with $300 \mathrm{mM}$ D-glucose in phosphate-buffered saline, $\mathrm{pH} 7.4$, at $25^{\circ} \mathrm{C}$. Samples were removed at intervals, and glucose concentration in erythrocytes was estimated on perchloric acid extracts.
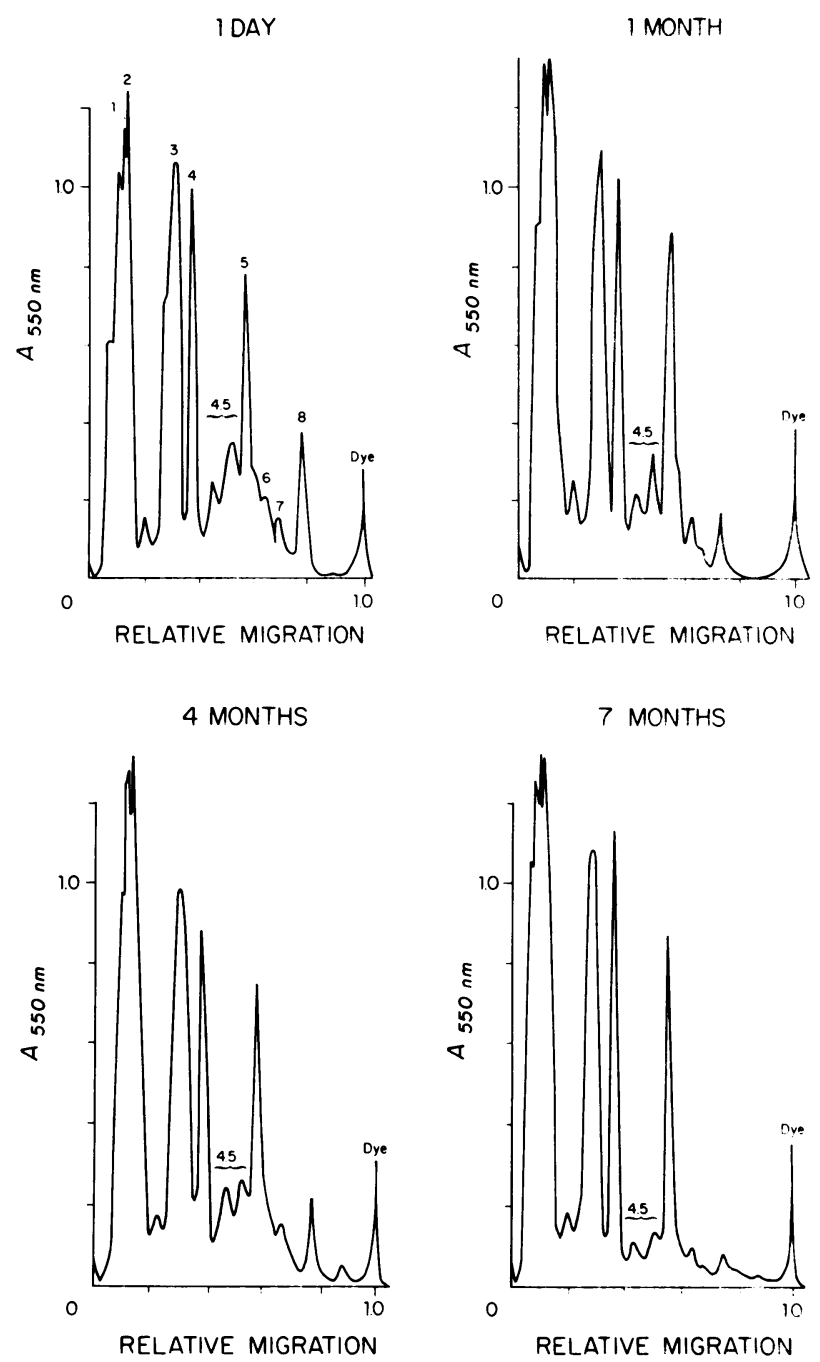

FIGURE 2 SDS-PAGE of erythrocyte ghosts of guinea pigs of various ages. Gels were stained by Coomassie Blue and scamed at $550 \mathrm{~nm}$ with a Gilford spectrophotometer.

$4-$, and 7-mo-old guinea pig, accounts for $\sim 11.0,8.9$, 6.2 , and $4.1 \%$ of Coomassie Blue-stained materials, respectively. The only other major change noted in the electrophoretic pattern was a progressive loss of bands seven and eight.

To examine these changes in greater detail, extrinsic ghost proteins that occupy bands one, two, five, and six were largely removed from ghosts by treatment with $0.1 \mathrm{mM}$ EDTA followed by $0.5 \mathrm{M} \mathrm{NaCl}$ as described in Methods. Fig. 3 shows the electrophoretogram of such treated ghosts at each age. The decrease of zone 45 during maturation is apparent.

Purification of zone 4.5. The EDTA-NaCl extracted ghosts were incubated with $0.5 \%$ Triton X-100 and the solubilized fraction in Triton X-100 was further purified on a column of DEAE-cellulose as indicated in Methnds. 


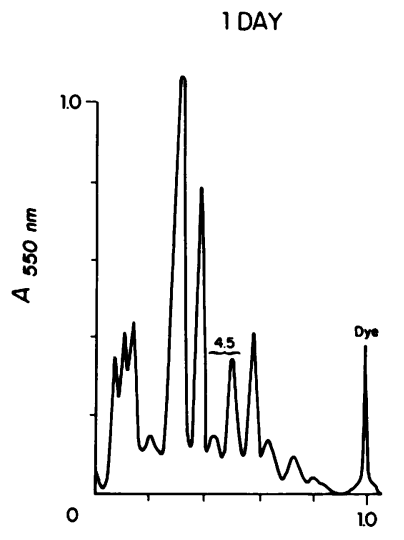

RELATIVE MIGRATION

4 MONTHS

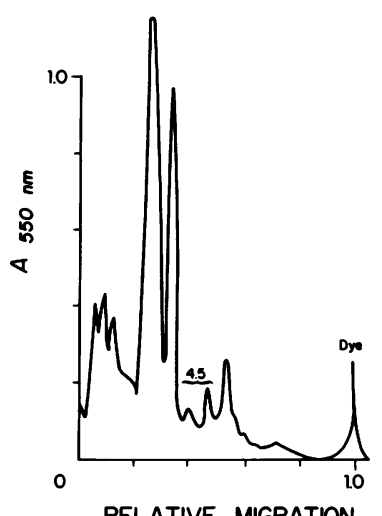

RELATIVE MIGRATION

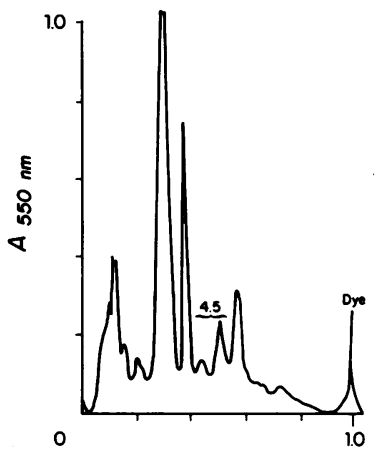

RELATIVE MIGRATION

7 MONTHS

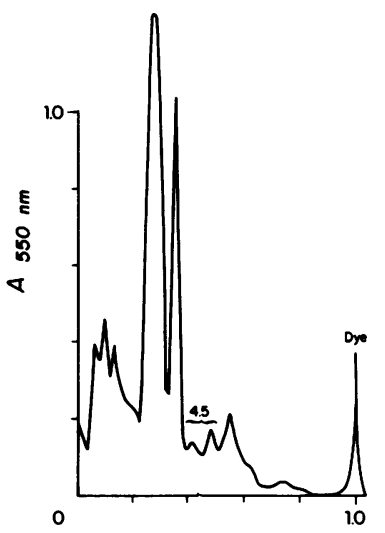

RELATIVE MIGRATION

FIGURE 3 SDS-PAGE of EDTA-NaCl extracts of ghosts of erythrocytes of various ages. Ghosts were treated with $0.1 \mathrm{mM}$ EDTA, followed with $0.5 \mathrm{M} \mathrm{NaCl}$ to remove spectrin bands (Methods). Gels were stained by Coomassie Blue and scanned at $550 \mathrm{~nm}$ with a Gilford spectrophotometer.

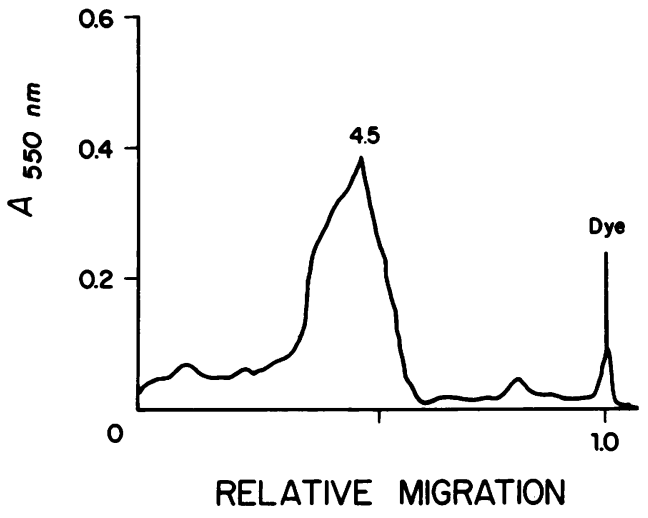

FIGURE 4 SDS-PAGE of DEAE purified EDTA-NaCl extracted guinea pig erythrocyte ghosts. Gels were stained by Coomassie Blue and scanned at $550 \mathrm{~nm}$ with Gilford spectrophotometer.

The DEAE-cellulose column eluate obtained from erythrocyte membranes from 7-mo-old guinea pigs contained only about $0.5 \%$ of the total ghosts protein, whereas $4.3 \%$ of the protein from erythrocyte membranes from newborn guinea pigs appeared in this fraction. A single major band was found on electrophoretogram of SDS-PAGE of pooled fractions from the column (Fig. 4). The result obtained closely resembles that described for human erythrocytes $(1,2)$.

Reconstitution in liposomes and assay of glucose transport system. Table I presents the results of measurement of uptake of D-glucose and of L-glucose by liposomes in which were incorporated Triton extracts or purified zone 4.5 of erythrocyte membranes from guinea pigs of various ages. D-Glucose uptake showed a dependence on glucose concentrations and time of incubation (data not shown). L-Glucose served

TABLE I

Reconstitution of D-Glucose Transport System

\begin{tabular}{|c|c|c|c|c|c|}
\hline \multirow{2}{*}{$\begin{array}{l}\text { Ghost protein } \\
\text { fraction }\end{array}$} & \multirow[b]{2}{*}{ Age } & \multirow{2}{*}{$\begin{array}{l}\text { Protein per } \\
\text { milliliter } \\
\text { liposome }\end{array}$} & \multicolumn{2}{|c|}{$\begin{array}{l}\text { Uptake of total } \\
\text { radioactivity }\end{array}$} & \multirow{2}{*}{$\begin{array}{l}\text { Specific activity of } \\
\text { D-glucose minus } \\
\text { L-glucose uptake }\end{array}$} \\
\hline & & & D-glucose & L-glucose & \\
\hline & & $\mu g$ & & & $\begin{array}{c}\text { nmoles/mg } \\
\text { protein/min }\end{array}$ \\
\hline \multirow[t]{4}{*}{ Triton extracts } & $1 \mathrm{~d}$ & 210 & 0.33 & 0.026 & 1.22 \\
\hline & $1 \mathrm{mo}$ & 310 & 0.28 & 0.020 & 0.70 \\
\hline & $4 \mathrm{mo}$ & 190 & 0.12 & 0.035 & 0.38 \\
\hline & $7 \mathrm{mo}$ & 220 & 0.021 & 0.032 & - \\
\hline \multirow[t]{3}{*}{ Purified zone 4.5} & $1 \mathrm{~d}$ & 66 & 0.61 & 0.020 & 7.51 \\
\hline & $1 \mathrm{mo}$ & 60 & 0.46 & 0.025 & 6.09 \\
\hline & $7 \mathrm{mo}$ & 56 & 0.021 & 0.021 & - \\
\hline none & & - & 0.020 & 0.023 & - \\
\hline
\end{tabular}

The preparation of ghost protein fractions, their incorporation into liposomes, and the measurement of uptake of D- and L-glucose into liposomes is described in the text. 
as a measure of nonspecific uptake. Decrease of glucose uptake in reconstituted liposomes of Triton extracts during development, paralleled the results obtained in the glucose transport assay with intact erythrocytes. The high specific activity for glucose uptake of purified preparation strongly suggests that the protein of zone 4.5 from guinea pig participates in glucose transport.

\section{DISCUSSION}

Newborn guinea pig erythrocytes are quite permeable to glucose, the sugar entering guinea pig erythrocytes at a rate similar to that found in human erythrocytes. However, there is a progressive loss of the ability of glucose to enter guinea pig erythrocytes so that by the time a guinea pig is 7 mo of age, glucose permeability can no longer be demonstrated.

The loss of permeability of guinea pig erythrocytes to glucose could be caused by the development, in postnatal life, of: $(a)$ erythrocytes in which glucose could not reach a normal glucose carrier; $(b)$ a "glucose carrier" that had lost its affinity for D-glucose; or $(c)$ absence of the glucose carrier protein. The first of these possibilities was eliminated by our finding that although liposomes prepared from Triton extracted newborn cells could preferentially take up D-glucose, no such binding was observed when Triton extracts from adult erythrocytes were used. The actual disappearance of the glucose carrier molecule was demonstrated by showing that the quantity of proteins in zone 4.5 , the region of the electrophoretic pattern that manifests glucosebinding characteristics $(1,2)$, diminishes markedly with maturation of guinea pigs. Lesser decreases were observed in bands seven and eight. It is of interest that band seven is present in partially purified glucosebinding extracts of human erythrocyte membranes (1).

Our studies not only serve to indicate that the loss of glucose transport capacity of guinea pig erythrocytes during maturation is caused by the loss of the glucose carrier protein, but support earlier studies that suggest that the subunits of the transport of protein are found in zone 4.5 of the SDS-PAGE protein pattern of erythrocytes membranes.

\section{ACKNOWLEDGMENT}

This work was supported in part by grant HL 07449 from the National Institutes of Health.

\section{REFERENCES}

1. Kasahara, M., and P. C. Hinkle. 1977. Reconstitution and purification of the D-glucose transporter from human erythrocytes. J. Biol. Chem. 252: 7384-7390.

2. Kahlenberg, A., and C. A. Zala. 1977. Reconstitution of D-glucose transport in vesicles composed of lipids and intrinsic protein (zone 4.5) of the erythrocyte membrane. J. Supramol. Struct. 7: 287-300.

3. Baldwin, S. A., J. M. Baldwin, F. R. Gorga, and G. E. Lienhard. 1979. Purification of the cytochalasin B binding component of the human erythrocyte monosaccharide transport system. Biochim. Biophys. Acta. 552: 183-188.

4. Widdas, W. F. 1955. Hexose permeability of fetal erythrocytes. J. Physiol. (Lond.). 127: 318-327.

5. Laris, P. C. 1958. Permeability and utilization of glucose in mammalian erythrocytes. J. Cell. Physiol. 51: 273-307.

6. Beutler, E., C. West, and K. G. Blume. 1976. The removal of leukocytes and platelets from whole blood.J. Lab. Clin. Med. 88: 328-333.

7. Beutler, E. 1975. Red Cell Metabolism. A Manual of Biochemical Methods. 2nd edition. Grune \& Stratton, Inc., New York.

8. Dodge, J. T., C. Mitchell, and D. J. Hanahan. 1963. The preparation and chemical characteristics of hemoglobinfree ghosts of human erythrocytes. Arch. Biochem. Biophys. 100; 119-130.

9. Fairbanks, G., T. L. Steck, and D. F. H. Wallach. 1971. Electrophoretic analysis of the major polypeptides of the human erythrocyte membrane. Biochemistry. 10: 26062617.

10. Holloway, P. W. 1973. A simple procedure for removal of triton X-100 from protein samples. Anal. Biochem. 53: 304-308.

11. Lowry, O. H., N. Y. Rosenbrough, A. L. Farr, and R. J. Randall. 1951. Protein measurement with the Folin phenol reagent. J. Biol. Chem. 193: 265-275.

12. Steck, T. L. 1974. The organization of proteins in the human red blood cell membrane. J. Cell. Biol. 62: 1-19. 